\title{
Multicentric lymphoma in sheep (case report)
}

\author{
Linfoma multicêntrico em ovino (relato de caso)
}

\author{
SANTOS, Ederson dos ${ }^{1}$ \\ https://orcid.org/0000-0003-1285-5412 \\ KALB, Ana Luiza ${ }^{1}$ \\ https://orcid.org/0000-0002-9204-4048 \\ BARBOSA, Antônio Amaral ${ }^{1}$ \\ https://orcid.org/0000-0001-6062-3486
}

\author{
RABASSA, Viviane Rohrig ${ }^{1}$ \\ http://orcid.org/0000-0002-0088-0605 \\ CORRÊA, Marcio Nunes ${ }^{1 *}$ \\ http://orcid.org/0000-0003-0855-2750
}

${ }^{1}$ Universidade Federal de Pelotas (UFPel); Faculdade de Veterinária (FV); Departamento de Clínicas Veterinária; Campus Universitário, Núcleo de Pesquisa, Ensino e Extensão em Pecuária (NUPEEC), Avenida Eliseu Maciel sem número. Campus Capão do Leão, Pelotas RS, Brasil - 96010-000.

*Corresponding author: edersonnupeec@gmail.com

\begin{abstract}
The present study describes a case report in sheep with multicentric lymphoma. Clinical examination revealed the animal presented tachycardia, tachypnea, congested ocular mucous membranes, fever, cachexia, mild dehydration, decreased ruminal motility, difficulty in standing, and dysuria. Supportive treatment and complementary examination (complete blood count, radiography, ultrasound and abdominocentesis) were performed. The results showed neutrophilic leukocytosis, persistent lymphocytosis, exudate with high cell concentration, and imaging examination showed abundant fluid in the abdominal cavity, and enlarged iliac and mesenteric lymph nodes. Due to the severe clinical condition, the animal died and referred for necropsy. Samples from different organs were collected for histopathological analysis. At necropsy, abundant light brown exudate was observed in the thoracic and abdominal cavities, multiple white lobulated masses in different organs, in addition to pink, irregular, multifocal and coalescent nodules in the omentum, with neoplastic cells arranged in cords and cloak of cells supported by a thin fibrovascular stroma. Macroscopic and microscopic findings are characteristic of multicentric lymphoma.
\end{abstract}

Keywords: Neoplasm, lymphoid tissue, ovine

\section{RESUMO}

O presente trabalho descreve um relato de caso em ovino. No exame clínico o animal apresentou taquicardia, taquipnéia, mucosas oculares congestas, febre e caquexia, grau

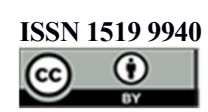


de desidratação leve, diminuição de motilidade ruminal, dificuldade em se manter em estação, além de disúria. Realizou-se tratamento de suporte e exames complementares (hemograma, radiografia, ultrassonografia e abdominocentese). Os resultados dos exames complementares demostraram leucocitose por neutrofilia e linfocitose persistente, presença de exsudato contendo elevada concentração celular, e exames de imagem indicando presença abundante de líquido na cavidade abdominal, e presença de linfonodos ilíacos e mesentéricos em tamanho aumentado. $\mathrm{O}$ animal veio a óbito em decorrência da severidade do quadro clínico, sendo encaminhado para necrópsia. Foram coletados fragmentos de diversos órgãos para análise histopatológica. Na necrópsia, observou-se grande quantidade de exsudato pardo-claro nas cavidades abdominal e torácica, múltiplas massas brancacentas e lobuladas em diferentes órgãos, além de nódulos rosados, irregulares, multifocais e coalescentes no omento com células neoplásicas que arranjavam-se em cordões e manto e, eram sustentadas por um fino estroma fibrovascular. Os achados macroscópicos e microscópicos são característicos de linfoma multicêntrico.

Palavras- chave: Neoplasia, tecido linfoide, exames complementares

\section{INTRODUCTION}

Lymphoma or lymphosarcoma is a lymphoid tumor that originates in solid lymphohematopoietic organs and lymphoid aggregates associated with mucous membranes (Fighera et al., 2002). According to Vail \& Young (2007), they are neoplastic diseases derived from lymph reticular cells, manifested in tissues and/or organs in which lymphoid components are aggregated, exhibiting malignant biological behavior.

Such a disease seems to have a higher prevalence in companion animals, considered one of the most common neoplasms in dogs and cats, with rates that can reach up to 200 cases per 100 thousand animals/year (Morrison, 2004). In ruminants, lymphoma has been more diagnosed in dairy cattle (Barros, 2007), and its occurrence is associated with the bovine Leukemia virus (BLV). Sheep is also susceptible to the virus, especially when young (Anjos, 2010), sporadically, being found mainly in the inspection of animals in slaughterhouses (Dixon,
1984). It is reported that about $30-60 \%$ infected young sheep develop B-cell lymphosarcoma (Valli, 2007). In addition to cattle and sheep, lymphomas can occur in buffaloes (Vale-Echeto, 2009), and equines (Ramos, 2008; Pereira, 2020).

The economic importance of this disease is due to the condemnation of carcasses in slaughterhouses, disposal and/or death of animals, costs with diagnostic tests and secondary infections (Silva-Filho et al., 2011). Clinical signs are nonspecific, such as: progressive weight loss, cachexia, apathy, fever, dyspnea (DiGrassie et al., 1997; Anjos et al., 2010; Rego et al., 2015), in this way, the definitive diagnosis only occurs with the post mortem examination. Recent studies indicate that lymphoma is responsible for about 3\% death in adult sheep (Wilson, 2017). According to Porta (2019), about 100\% sheep infected with BLV develop persistent lymphocytosis, with the majority progressing to the development of lymphosarcoma. 
Given the scarcity of studies reporting the occurrence of neoplasms in small ruminants, with clinical follow-up and complementary examination, the present study aimed to describe a case of multicentric lymphoma in a sheep.

\section{MATERIAL AND METHODS}

In March 2020, a mixed breed sheep, approximately 2 years old, part of a flock of approximately 100 sheep raised extensively in a native field in the municipality of Capão do Leão, State of Rio do Grande do Sul, was treated at the veterinary hospital at the Federal University of Pelotas. The anamnesis with the technician responsible for the property revealed that dairy cattle were farmed on the same property, where $60 \%$ animals tested positive for leukosis in a test done 60 days ago using the agar gel immunodiffusion technique (AGID) to detect antibodies against the Bovine Enzootic Leukosis virus and that the animal had previously been treated with doramectin-based endectocide, and the contact was made because the animal entered in sternal decubitus.

In addition, only this animal had clinical symptoms and approximately 5 days of evolution of the disease on the property, when the patient was apathetic, with oliguria, dysuria and spending most of the day in decubitus.

During the clinical examination (Radostits et al., 2007), the animal presented tachycardia, tachypnea, congested ocular mucous membranes, fever, cachexia, mild dehydration, decreased ruminal motility, difficulty in standing, and dysuria. There was no increase in size in superficial lymph nodes. Supportive treatment was given by administering $50 \%$ glucose solution (1 $\mathrm{mL} / \mathrm{kg})$, sorbitol $(20 \mathrm{~mL})$, calcium borogluconate $(150 \mathrm{mg} / \mathrm{kg})$, ketoprofen (3 $\mathrm{mg} / \mathrm{kg}$ ) and a compound a based on vitamin B12 (10 mL). Subsequently, gentamicin $(4 \mathrm{mg} / \mathrm{kg})$ and ketoprofen (3 $\mathrm{mg} / \mathrm{kg}$ ) were administered intramuscularly.

Blood samples were collected in vacuum tubes with $10 \%$ EDTA for a complete blood count. Transabdominal ultrasound exams, ultrasound-guided paracentesis, and pelvis and abdomen radiography were also performed in order to seek a more detailed diagnosis of the case.

Hematological analysis was performed by the impedance technique using the semi-automated cell counter Celm CC530 (Celm, Brazil), the leukocyte differential was performed using blood smears stained with Panotype (Laborclin, Brazil) and the reading was done under a microscope Nikon Eclipse E200 (Nikon, Japan) at 1,000x magnification.

For radiographic analysis, an AGFA digitizer was used, making left laterallateral and ventral-dorsal projections of the abdomen and pelvis, and for the ultrasound examination of the abdominal cavity, the Ultrasound Ultramedic infinit $7 \mathrm{v}$. with the animal in quadruped position using a $3.5 \mathrm{MHzl}$ convex transducer.

Due to the severe clinical condition, the patient did not resist and died on the fourth day of hospitalization. The animal was sent to Regional Diagnostic Laboratory (LRD) of UFPel for post mortem examination. During necropsy, organ fragments (heart, lung, prestomachs, abomasum, intestines, lymph nodes, parietal pleura, peritoneum, omentum, diaphragm, kidneys, bladder, rectum, spleen) were collected and fixed in $10 \%$ formaldehyde, processed for histology and stained with hematoxylin and eosin (HE). 


\section{RESULTS AND DISCUSSION}

The results of the blood tests are listed in Table 1. The results showed leukocytosis due to neutrophilia and lymphocytosis (Wittwer, 2015; Thrall, 2015), with the presence of reactive lymphocytes in both tests, with an even greater increase in leukocytes in the second test. Several authors report the occurrence of persistent lymphocytosis in cattle with lymphosarcoma (Murakami, 1994; Flores, 2007; Thrall, 2015), and Kenyon (1981) observed persistent lymphocytosis in about $40 \%$ cases of sheep experimentally infected with the bovine leukemia virus and diagnosed with lymphosarcoma.

In the red series, no significant alterations suggestive of pathological changes were found, only mild hypochromasia, indicating a decrease in erythrocyte hemoglobin. However, the finding of neutrophilic leukocytosis and persistent lymphocytosis can occur in cases with a diagnosis of lymphoma (Thrall, 2015). According to Flores (2007) and Barros (2007), the increase in the number of lymphocytes occurs due to a proliferation of circulating $B$ lymphocytes in animals that have retrovirus infection, in this case the bovine leukemia virus.

Table 1. Blood count of a sheep with suspected multicentric lymphoma.

\begin{tabular}{cccccccc}
\hline \multicolumn{4}{c}{ Blood count } & & \multicolumn{3}{c}{ White blood cell count } \\
\hline Parameter & Result 1 & Result 2 & Reference & Parameter & Result 1 & Result 2 & Reference \\
\hline Red cells & $8.81 \times 10^{6}$ & $9.69 \times 10^{6}$ & $9.0-15$ & Leukocytes & 39,600 & 46,200 & $4,000-12,000$ \\
Hemoglobin & $9.6 \mathrm{~g} / \mathrm{dL}$ & $10.5 \mathrm{~g} / \mathrm{dL}$ & $9.0-15$ & Segmented & $21,780(55 \%)$ & $24,948(54 \%)$ & $700-6,000$ \\
Hematocrit & $34.00 \%$ & $37.40 \%$ & $27-45$ & Rods & $0(0 \%)$ & $0(0 \%)$ & Raros \\
VCM & $38.6 \mathrm{fl}$ & $38.6 \mathrm{fl}$ & $28-40$ & Lymphocytes & $17,820(45 \%)$ & $19,866(43 \%)$ & $2,000-9,000$ \\
CHCM & 28.2 & 28.1 & $31-34$ & Monocytes & $0(0 \%)$ & $924(2 \%)$ & $0-750$ \\
Platelets & 2886 & 3776 & $100-800$ & Eosinophils & $0(0 \%)$ & $0(0 \%)$ & $0-1,000$ \\
& & & & Basophils & $0(0 \%)$ & $0(0 \%)$ & $0-300$ \\
\hline
\end{tabular}

Source: SCHALM'S Veterinary Hematology (2010). Automation: Sysmex pocH-100iV

The collection of peritoneal fluid by abdominocentesis revealed exudate characteristics. The physical examination showed reddish/opaque color, semi-cloudy appearance, density of $1.020, \mathrm{pH} 6.0$, a trace of protein and two traces of occult blood, with 1,500 cells/uL. Cell counts above 1,000 cells/uL, density above 1.018 and turbidity of the sample indicate peritonitis (Wittwer, 2015).

In the cytological analysis, the sample showed medium cellularity, predominance of medium and large immature lymphocytes, with a small amount of cytoplasm and large central nucleolus, presence of some intact segmented neutrophils, rare macrophages and some red blood cells. In cattle and horses, normally mature and non-degenerate neutrophils predominate and a low number of lymphocytes (AlRukibat, 2006), however in this case, the cell characterization findings confirm the possible diagnosis of lymphoid tissue neoplasm (Thrall, 2015). In the literature, the analysis of peritoneal fluid in small ruminants is more commonly 
performed in cases of urinary tract obstruction (House, 1992), and a high number of immature and degenerate lymphocytes suggest the occurrence of lymphosarcoma. Thus, this finding also characterizes this analysis as an important tool in the definitive diagnosis of these diseases.

Left lateral-lateral and ventral-dorsal radiographic projections of the abdomen and pelvis are illustrated in Figure 1. The radiological findings showed a decrease in the definition of the contours of the abdominal organs due to the liquid radiopacity in the abdominal cavity, presence of gas and heterogeneous food content in the gastrointestinal tract and preserved musculoskeletal tissues, suggesting ascites/peritonitis/peritoneal effusion. Despite the importance of diagnosing abdominal conditions in small ruminants (House, 1992), there are few radiographic studies with sheep in the literature, and these emphasize the diagnosis of pregnancy in most cases (Wenham \& Robinson, 1972); this is the first study demonstrating radiographic examination on a sheep with lymphosarcoma.

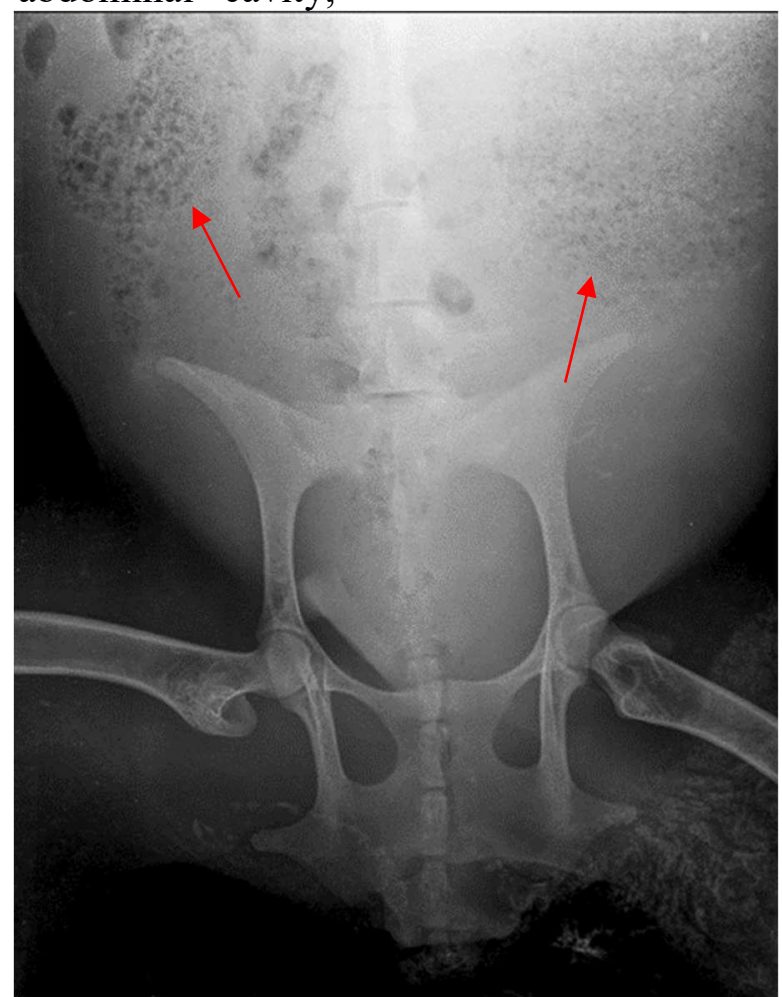

Figure 1. Radiographic image of the ventral-dorsal projection of the abdominal cavity in sheep with multicentric lymphoma, showing a decrease in the definition of the contours of abdominal organs due to liquid radiopacity in the abdominal cavity, suggesting ascites/peritonitis/peritoneal effusion (indicated by the arrows).

Differently from that addressed by Rego et al. (2015) using ultrasound examination of the thoracic cavity, the ultrasound examination in this case was performed in the abdominal cavity
(Scott, 2005), as illustrated in Figure 2, with the animal standing, using a 3.5 $\mathrm{MHz}$ linear transducer. The evaluation showed a large accumulation of fluid in the abdominal cavity, a full urinary 
bladder, and enlarged mesenteric and iliac lymph nodes. These results corroborate Yam (2002), who evaluated the abdominal cavity of a dog diagnosed with multicentric lymphoma, and identified lymph nodes of increased size, reduced echogenicity in relation to mesenteric fat, with hyperechoic areas, although some with echogenic center and hypoechoic rim. It was not possible to perform the ultrasound examination through the transrectal route due to the presence of a mass of approximately 6 centimeters in diameter between the pelvic floor and the ceiling of the vaginal wall, which is why the animal arched its back during urination. Ultrasonography is an important tool for the rapid diagnosis of disorders in the abdominal cavity in sheep (Scott \& Sargison, 2010), however there are no reports in the literature that correlate ultrasound images with the occurrence of lymphomas in this species.

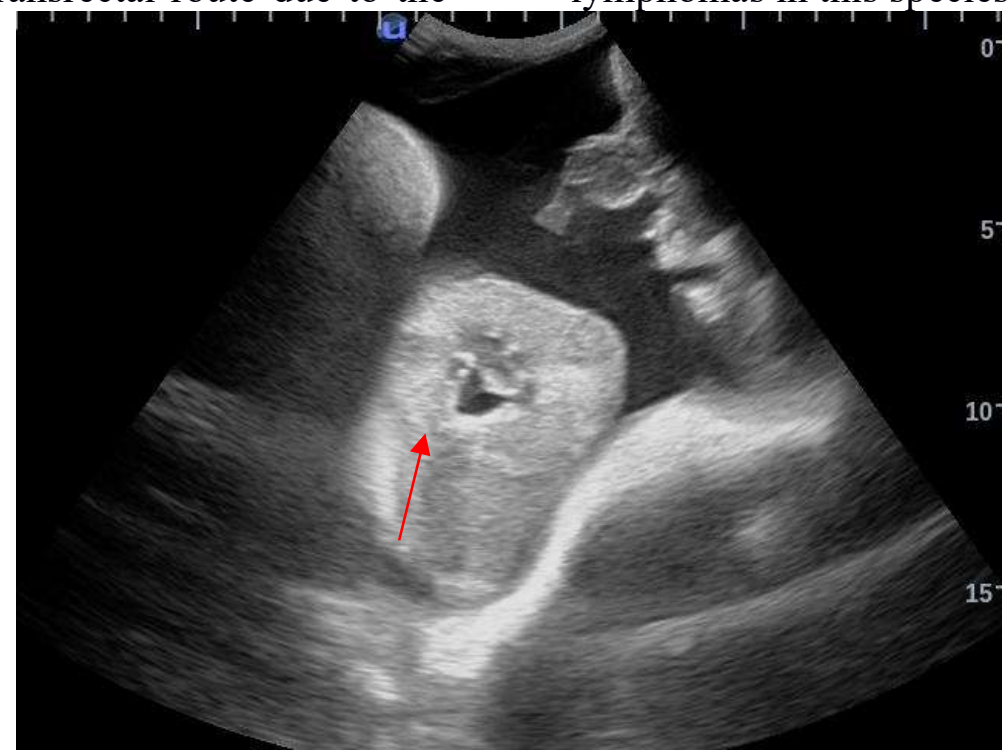

Figure 2. Ultrasound image of the abdominal cavity of a sheep with multicentric lymphoma, with enlarged mesenteric and iliac lymph nodes (indicated by the arrow).

At necropsy, in the abdominal and thoracic cavities, abundant pale brown exudate and multiple white lobulated masses were observed in the lymph nodes, parietal pleura, peritoneum and other organs. Serosa of the pre-stomachs, intestine and uterus had multiple white, homogeneous nodules, multifocal to coalescent, soft consistency to the cut (Figure 3). Inside the masses, there was proliferation of neoplastic cells, supported by a thin fibrovascular stroma.
Thus, macroscopic and microscopic findings are characteristic of malignant multicentric lymphoma of hematopoietic origin. Results similar to those described were reported by Johnstone \& Manktelow (1978), Anjos (2010), Rego (2015) when performing necropsy in sheep diagnosed with spontaneous multicentric lymphosarcoma, and in experimental infections by Olson \& Baumgartener, (1976) and Djilali \& Parodi (1989) 


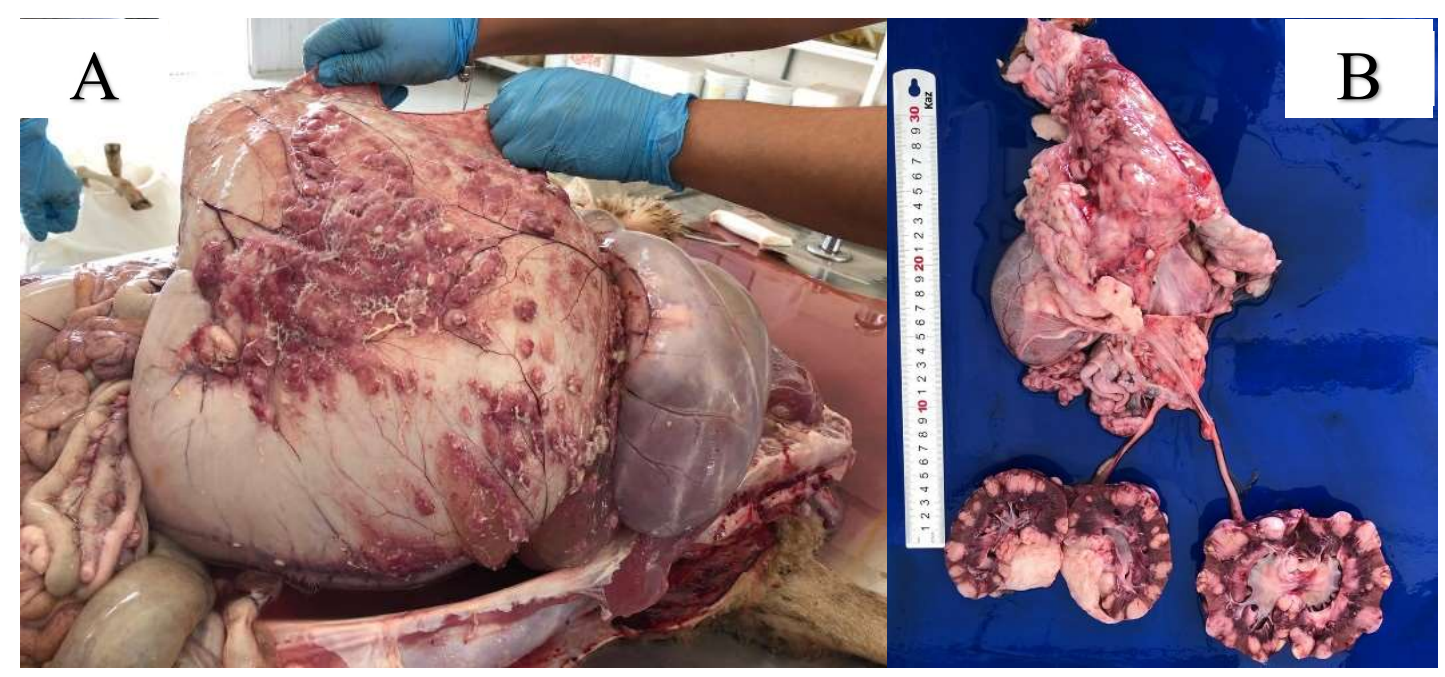

Figure 3. A: Image of the necropsy of the sheep with multicentric lymphoma showing the serosa of the pre-stomachs and intestine with multiple white, homogeneous and multifocal nodules. B: Image of the necropsy of the sheep with multicentric lymphoma showing kidneys, uterus and serous layer of the bladder with multiple white, homogeneous and multifocal nodules.

In sheep, lymphomas may be of idiopathic origin or due to infection by the bovine leukemia virus, a fact to be considered in the present report, since they coexist with infected cattle. Nevertheless, it must be taken into account that despite the high susceptibility of sheep to this virus, cases of spontaneous infection are rare, a result confirmed by anamnesis, clinical examination, histopathology and AGID. Finally, it is important to note that the advance in cell specificity that causes such diseases is becoming more and more necessary every day, considering that there are possible consequences in the organism that, probably, may be

\section{REFERENCES}

AL-RUKIBAT, R.K.; BANI ISMAIL, Z.A.; AL-MAJALI, A.M.; ALZGHOUL, M.B. Peritoneal fluid analysis on adult, nonpregnant Awassi sheep. Veterinary Clinical Pathology, v.35 n.2, p.215-218, 2006. specific to each type of cell. In humans, for example, lymphomas can be divided into 2 large groups: Hodgkin's lymphoma and non-Hodgkin's lymphoma. The first is characterized by the proliferation of neoplastic cells of variable morphology called ReedSternberg cells (Monteiro, 2016). In turn, the second type leads to somatic mutations of lymphoid cells, B, T or natural killer (Milito, 2002). Thus, in animals it is increasingly necessary to distinguish the origin of neoplastic cells of lymphoid origin, in order to improve the basis for therapeutic and prognostic approaches.

ANJOS, B.L.; TROST, M.E.; DIEFENBACH, A.; GRESSLER, L.T.; IRIGOYEN, L.F. Linfossarcoma de células B multicêntrico em uma ovelha. Acta Scientiae Veterinariae, v.38, n.3, p.315-318, 2010. 
BARROS, C.S.L. Leucose bovina, p.159-168. In: RIET-CORRÊA, F.;

SCHILD, A.L.; LEMOS, R.A.A.; BORGES, J.R.J. Doenças de

Ruminantes e Equideos, Ed. 3, v. 2, Palloti: Santa Maria, p.159-167, 2007.

DIGRASSIE, W.A.; WALLACE, M.A.; SPONENBERG, D.P. Multicentric lymphosarcoma with ovarian involvement in a Nubian goat. The Canadian veterinary journal, v.38, n.6, p.383-384, 1997.

DJILALI, S.; PARODI, A. The BLVInduced Leukemia-Lymphosarco-ma Complex in Sheep. Veterinary Immunology and Immunopa-thology, v.22, p 233-244, 1989.

DIXON, R. J., MORIARTY, K. M., \& JOHNSTONE, A. C. An immunological classification of ovine lymphomas. Journal of Comparative Pathology, v. 94, n.1, p. 107-113, 1984.

FIGHERA, R.A.; SOUZA, T.M.; BARROS, C.S.L. Linfossarcoma em cães. Ciência Rural, v.32, n.5, p.895899, 2002.

FLORES, E.F. Virologia Veterinária. Santa Maria: Ed. da UFSM, 2007. 888 p.

HOUSE, J.K.; SMITH, B.P.; VANMETRE, D.C.; FECTEAU, G.; CRAYCHEET, T.; NEVES, J.

Ancilarry Testes for Assessment of the Ruminant Digestive System. Veterinary Clinics of North America: Food Animal Practice, v.8, n.2, p.203232, july 1992.
JOHNSTONE, A.C.; MANKTELOW, B.W. The Pathology of Spon-taneously Occurring Malignant Lymphoma in Sheep. Veterinary Pathology, v.15, p.301-312, 1978.

KENYON, S.J.; FERRER, J.F.; MCFLEEY, R.A.; GRAVES, D.C. 1981. Induction of lymphosarcoma in sheep by bovine leukemia virus. Journal of the National Cancer Institute, v.67, n.5, p.1157-1163, 1981.

MILITO, C.B.; MORAIS, J.C.; NUCCI, M.; PULCHERI, W.; SPECTO, N. Classificação dos linfomas nãoHodgkin: estudo morfológico e imunoistoquímico de 145 casos. Jornal Brasileiro de Patologia e Medicina Laboratorial, v.38, n.4, 2002.

MONTEIRO, T.A.F.; ARNAUD, M.V.C.; MONTEIRO, J.L.F.; COSTA, M.R.M.; VASCONCELOS, P.F.C. Linfoma de Hodgkin: aspectos epidemiológicos e subtipos diagnosticados em um hospital de referência no Estado do Pará, Brasil.

Revista Pan-Amazônica de Saúde, v.7, n. 1, 2016.

MORRISON, W. B. Lymphoma in dogs and cats, p.3-4, 2004.

MURAKAMI, K.; OKADA, K.; IRAWA, Y.; AIDA, Y. Bovine leukemia virus induces CD5 ${ }^{-}$Bcells lymphoma in sheep despiste temporarily increasing $\mathrm{CD} 5{ }^{+}$Bcells in asyntomatic stage. Virology, v.202, p. 458465,1994 .

OLSON, C.; BAUNGARTENER, L.E. 1976. Pathology of lymphosarcoma in sheep induced with bovine leukemia virus. Cancer Research, v.36, n.7, pt 1, p.2365-2373, 1976. 
PEREIRA, A.T.; PEREIRA, A.P.M.; BRANDOLT, I.M.C.; POZZOBOM, R.; COSTA, M.M.; ANJOS, B.L.; PAVARINI, S. Linfoma Multicêntrico de Células T em uma Potra Crioula, Semina: Ciências Agrárias, Londrina, v.41, n.2, p.725-730, mar/abri. 2020.

PORTA, N. G.; ALVAREZ, I.; ARCHILLA, G. S.; RUIZ, V.; ABDALA, A.; TRONO, K. Experimental infection of sheep with Bovine leukemiavirus (BLV):

Minimum dose of BLV-FLK cells and cell-free BLV and neutralization activity of natural antibodies. Revista Argentina de Microbiología, v.51, n.4, p.316-323, 2019.

RADOSTITS, O. M.; GAY, G.C.; BLOOD, D.C.; HINCHCLIFF, K.W. Clínica veterinária: um tratado de doenças dos bovinos, ovinos, suínos, caprinos e equinos, 9.ed. Rio de Janeiro: Guanabara Koogan, 2007. 1737 p.

RAMOS, A.T.; SOUZA, A.B.; NORTE, D.M.; FERREIRA, J. L. M; FERNANDES, C.G. Tumores em animais de produção: aspectos comparativos. Ciência Veterinária, v.38, n.1, p.148-154, jan/fev, 2008.

REGO, O.; SOUZA, J.C.A.; MENDONÇA, C.L.; SILVA, R.J.; SILVA, N.A.A.; RIET-CORREA, F.; AFONSO, J.A.B. Ocorrência espontânea de linfoma maligno em ovelha: relato de caso. Ciência Veterinária nos Trópicos, Recife-PE, v.18, n.1, p.26-31, janeiro/abril, 2015.

SILVA-FILHO, A.P.; AFONSO, J.A.B.; SOUZA, J.C.A.; RIETCORREA, F.; DANTAS, A.F.;
DANTAS, A.C.; COSTA, N.A.; MENDONÇA, C.L. Linfossarcoma em bovinos no Agreste Meridional de Pernambuco. Pesquisa Veterinária Brasileira, v.31, n.7, jul.2011.

SCOTT, P.R.; SARGISON, N.D.; MACRAE, A.; RHIND, S R. An outbreak os subacute fasciolosis in Soay Sheep: Ultrasonographic biochemical and histological studies. The Veterinary Journal, v.170, p.325-331, 2005.

SCOTT, P.R.; SARGISON, N.D. Ultrasonagraphy as an adjunct to clinical examination in sheep. Small Ruminant Research, v.92, p.108-119, 2010 .

THRALL, M.A.; WEISER, G.; ALLISON, R.W.; CAMPBELL, T.W. Hematologia e Bioquímica Clínica Veterinária, $2^{\circ}$ ed. Rio de Janeiro: Guanabara Kogan, 2015. 1590p.

VAIL, D.M.; YOUNG, K.M. Canine lymphoma and lymphoid leukemia. In: WITHROW, S.J.; VAIL, D.M. Withrow \& MacEwen's small animal clinical oncology, Philadelphia: W. B. Saunders Company, cap.31, p.699-733, 2007.

VALE-ECHETO, O.E.; MONTIELURDANETA, N.; SIMOES, D.; VALEOVIEDO, R.; PARRAMALDONADO, O.; VALE, O.G.O.; GARCÍA, A. Linfoma multicéntrico o linfossarcoma multicéntrico em búfalo de agua (Bubalus bubalis): estudio anatomopatológico. Reporte de un caso. Revista Científica FCV-LUZ, v.XIX, n.3, p.257 - 263, 2009. 
VALLI, V.E.O. Hematopoietic system. In: Maxie M.G. (Ed.) Jubb,

Kennedy, and Palmer's Pathology of

Domestic Animals. v.3, 5 ed

Philadelphia: Elsevier, p.107-324, 2007.

WENHAM, G.; ROBINSON, J.J.

Radiografic pregnancy diagnosis in sheep. The Journal of Agricultural Science, v.78, n.2, p.233-238, 1972.

WILSON, D.J.; BALDWIN, T.J.; KELLY, E.J. Diagnoses of primary cause of mortality in domestic sheep in the North American Intermountain West. Journal of Veterinary Science \& Technology, v.8, n.6, p.1-5, 2017.

WITTWER, F. Patología Clínica

Veterinária, UACh: Valdivia. 2015. 200p.

YAM, P.S.; JOHNSON, V.S.; MARTINEAU, H.M.; DICKIE, A.; SULLIVAN, M. Multicentric lymphoma with intestinal involviment in a dog. Veterinary Radiology \&

Ultrasond, v.43, n.2, p.138-143, 2002. 